\title{
Agrogenic Evolution of Automorphic Chernozems in the Forest-Steppe Zone (Belgorod Oblast)
}

\author{
Yu. G. Chendev ${ }^{a, *}$, O. S. Khokhlova ${ }^{b}$, and A. L. Alexandrovskiy ${ }^{c}$ \\ ${ }^{a}$ Belgorod National Research University, Belgorod, ul. Pobedy 85, 308015 Russia \\ ${ }^{b}$ Institute of Physicochemical and Biological Problems of Soil Science, Russian Academy of Sciences, \\ Institutskaya ul. 2, Pushchino, Moscow oblast, 142290 Russia \\ ${ }^{c}$ Institute of Geography, Russian Academy of Sciences, Staromonetnyi per. 29, Moscow, 119017 Russia \\ *e-mail: sciences@mail.ru \\ Received April 13, 2015
}

\begin{abstract}
Agrochronosequences of chernozems with different periods of their use in rainfed farming with application of traditional technologies have been studied in a typical forest-steppe area in Belgorod oblast. Certain stages in the development of these soils during more than two centuries of their agricultural use have been identified. These stages are related to changes in the intensity and direction of soil forming processes, such as soil compaction, soil aggregation, dehumification of the upper horizons, calcification of the soil profiles, argillization, etc. A significant impact on the soil changes during the agrogenic evolution of chernozems is exerted by the digging activity of burrowers, which is especially pronounced in the old-arable chernozems.
\end{abstract}

Keywords: chernozems, soil agrochronosequences, tillage, forest-steppe, stadial specificity of the agrogenic evolution, multiple study methods

DOI: $10.1134 /$ S 1064229317050040

\section{INTRODUCTION}

Investigations into the impact of tillage on the properties of chernozems have a long history. In different years, this problem was tackled by Dokuchaev [14], Kostychev [19, 20], Pankov [27, 28], Denisov [13], Aderikhin [2], Afanas'eva [3], Kokovina [18], Medvedev [25], Krupenikov [21], Orlov with coauthors [26], Shcheglov [40], Akhtyrtsev with coauthors [4], Lebedeva [24], Glazovskaya [12], Kozlovskii [17], and many other scientists. These studies allowed us to gain a better understanding of the essence of soil forming processes in plowed chernozems and their changes with time and to develop a set of methods aimed at conservation and reproduction of these soils as the most valuable nature resource of Russia. However, the diversity of the existing information on transformation of chernozems under the impact of tillage poses new problems related to the genesis of the new soil properties and processes in plowed chernozems. The changes in the morphogenetic character of plowed chernozems and in the intensity of a number of soil processes (in particular, dehumification) in them should be specially analyzed. It should be noted that, in some studies, the most important problem of the loss of organic matter from chernozems under the impact of tillage is considered not quite correctly: only the content of humus in the plow horizons is analyzed, whereas changes in the bulk density of the soils are ignored.
Orlov et al. [26] paid special attention to this problem. In many studies of agrogenic changes in chernozems, the major attention is paid to their results, which helps scientists to understand the direction of the transformation of chernozems $[1-4,10,13,21,28,35,40]$. However, the particular stages of this process are also important. Thus, it has been shown that the rate of the loss of organic matter from these soils decreases with time $[1-3,21,35,40]$. The works devoted to the stadial specificity of changes in other soil properties and soil forming processes in plowed chernozems are few in number [16, 17, 24, 25]. This situation encourages us to continue the study of plowed chernozems with a special emphasis on the stages of their transformation, the reasons for their changes with time, and the character of soil processes in the course of the long-term agricultural development of these soils.

\section{OBJECTS AND METHODS}

We studied chernozems on flat interfluves in the forest-steppe zone in the south of the Central Russian Upland within the administrative boundaries of Belgorod oblast (Fig. 1). All the investigated soils shared the same history of their agricultural development: from the initial shallow $(<15 \mathrm{~cm})$ tillage with a wooden ard or wooden plow drawn by a horse (up to 1930s) to deeper tillage by a tractor-drawn plow, including 


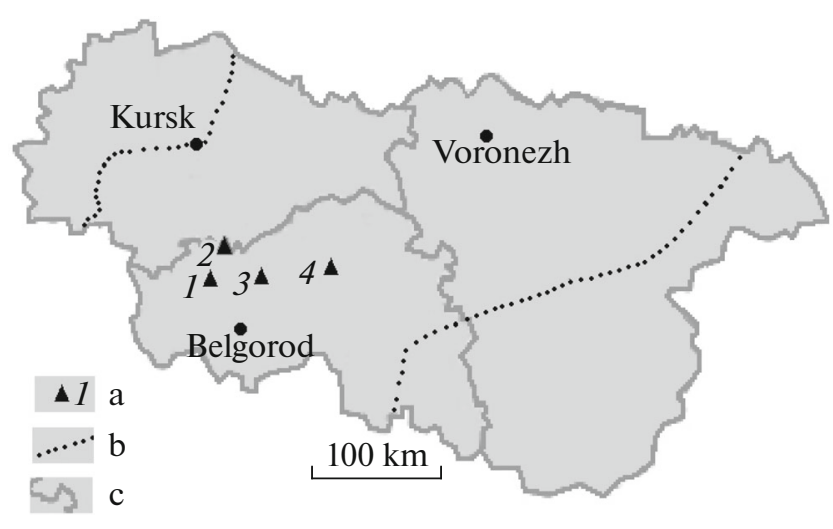

Fig. 1. Location of the key sites for the study of the agrotechnogenic evolution of forest-steppe chernozems: (a) key sites and their numbers, (b) northern and southern boundaries of the forest-steppe zone, and (c) administrative boundaries within the central chernozemic region. Numbers of key sites (here and in Fig. 3): 1-Verkhopen'e, 2-Safonovka, 3-Zhimolostnoe, and 4-Yur'evka.

moldboard plowing in the 1990s-2000s. In recent years, on all the plots, soil-saving tillage technologies-nonmoldboard plowing, minimal tillage, and zero tillage-have been applied. The rates of annually applied organic fertilizers on all the plots have never been higher than $6 \mathrm{t} / \mathrm{ha}$. Before the 1950s, no fertilizers were used. It was a common practice of agriculture in prerevolutionary Russia and in the first decades of the Soviet Union. In general, we should admit that extensive farming technologies prevailed on all the plots during a longer part of their agricultural exploitation; they did not ensure the restoration of the natural soil fertility. Unfortunately, this is still typical of a larger part of farmland in the central chernozemic region of Russia.

At the Verkhopen'e site (Ivnyansk district of Belgorod oblast), medium-deep slightly podzolized cher- nozems (Luvic Greyzemic Chernic Phaeozems (Loamic, Pachic)) [41] developed from the carbonate loesslike silty clay loam are found. These soils were formed under the natural oak-ash forests, whose fragments are still preserved in this area. According to the large-scale maps compiled in the end of the 18th century [31], the whole territory of the investigated agrolandscape was covered by the forests. A comparative analysis of the maps dating back to the 18th-early 20 th centuries shows that the forests were cut and replaced by arable land in several stages. The plots with plowed analogues of slightly podzolized chernozems under forests of 90, 120, and 240 years in age were identified at this site.

At the Safonovka (Ivnyansk district of Belgorod oblast), Yur'evka (Gubkin district), and Zhimolostnoe (Prokhorovka district) sites, the natural background soils were studied on vast plots with herbaceous vegetation near the corresponding settlements. These plots have never been converted to plowland; they have been used as hayfields and pastures. At the Safonovka and Yur'evka sites, the profiles of medium-deep typical and leached chernozems (Haplic Chernozems and Luvic Chernozems (Loamic, Pachic)) developed from the carbonate loesslike silty loam were described on these background plots. At the Zhimolostnoe site, the background soils were represented by the medium-deep silty clay loamy typical and leached chernozems (Haplic Chernozems and Luvic Chernozems (Loamic, Pachic)) developed from thin (up to 1.5-2 m) carbonate loesslike silty loam underlain by the Pre-Quaternary red-colored carbonate-free sandy silt loam.

Data on the particle-size distribution and some physicogeographical characteristics of background soils at the key sites are presented in Table 1.

To study the agrogenic evolution of chernozems, a wide range of methods was applied: the morphological analysis of the soil profiles, comparative-geo-

Table 1. Physiographic information on the key sites with the studied agrochronosequences of chernozems.

\begin{tabular}{|c|c|c|c|c|c|c|c|c|}
\hline \multirow[b]{2}{*}{ Site name } & \multirow[b]{2}{*}{ Coordinates } & \multirow[b]{2}{*}{$\begin{array}{l}\text { Absolute } \\
\text { height, } m\end{array}$} & \multicolumn{3}{|c|}{ Climate indices } & \multirow[b]{2}{*}{ Virgin soils } & \multicolumn{2}{|c|}{ Parent material } \\
\hline & & & $\begin{array}{c}\text { precipitation, } \\
\mathrm{mm}\end{array}$ & $\begin{array}{c}\text { mean annual } \\
\text { temperature, } \\
{ }^{\circ} \mathrm{C}\end{array}$ & HTC & & name & $\begin{array}{l}\text { physical } \\
\text { clay, \% }\end{array}$ \\
\hline Verkhopen'e & $\begin{array}{l}50^{\circ} 56^{\prime} 56.58^{\prime \prime} \mathrm{N} \\
36^{\circ} 17^{\prime} 18.83^{\prime \prime} \mathrm{E}\end{array}$ & 250 & 610 & +5.8 & 1.19 & $\begin{array}{l}\text { Slightly podzolized } \\
\text { chernozems }\end{array}$ & LCL & $45-55$ \\
\hline Safonovka & $\begin{array}{l}51^{\circ} 5^{\prime} 53.86^{\prime \prime} \mathrm{N} \\
36^{\circ} 23^{\prime} 44.44^{\prime \prime} \mathrm{E}\end{array}$ & 195 & 620 & +5.7 & 1.19 & Typical chernozems & LCL & $50-64$ \\
\hline Zhimolostnoe & $\begin{array}{l}50^{\circ} 57^{\prime} 3.38^{\prime \prime} \mathrm{N} \\
36^{\circ} 43^{\prime} 42.35^{\prime \prime} \mathrm{E}\end{array}$ & 240 & 600 & +6.0 & 1.15 & $\begin{array}{l}\text { Typical chernozems } \\
\text { transitional to } \\
\text { leached chernozems }\end{array}$ & TLCL & $42-54$ \\
\hline Yur'evka & $\begin{array}{l}51^{\circ} 3^{\prime} 13.59^{\prime \prime} \mathrm{N} \\
37^{\circ} 21^{\prime} 29.93^{\prime \prime} \mathrm{E}\end{array}$ & 235 & 580 & +5.9 & 1.12 & Typical chernozems & TLCL & $48-59$ \\
\hline
\end{tabular}

HTC-hydrothermic coefficient; LCL-loesslike calcareous loam, and TLCL—thin loesslike calcareous loam. 
graphic method, the method of soil agrochronosequences, the analysis of historical maps, the methods of physical and chemical soil analyses, the statistical methods, the micromorphological method, and the methods of radiocarbon dating of humus and pedogenic carbonates.

The major method was the method of soil agrochronosequences. This method was also used in previous studies $[6,10,11,16]$. However, in these studies, the soils of the plots located far from one another were mainly analyzed. This could cause some inaccuracy in the interpretation of the results because of the effect of the spatial heterogeneity of the parent materials and topographic conditions inevitable in the case of the large study area.

The historical cartographic method implied the work in the Russian State Archive of Old Acts with the purpose to identify key plots for the field study. We searched for large-scale plans created in different times (the period of the ordnance survey in the 1780s-1790s, the period of Special land survey in the 1860s-1870s, and, for some areas, large-scale maps developed at the beginning of the 20th century. These materials were compared with modern topographic maps. As a result, we identified key plots on flat automorphic interfluves (plakors) with the preserved areas of virgin soils and with the nearby areas of plowed soils with different durations of cultivation. This method was first used by Gedymin with coauthors in 1964 [10, 11]. Along with the use of historical cartographic materials, we specified the areas of investigation during the reconnaissance survey via talking to local people in order to obtain more detailed information about the history of agriculture and land use in these areas and the age of soil tillage. Thus, at the Yur'evka site, we discovered an additional object for our study: the soil of the recently (16 years) plowed plot used by a local farmer.

Each of the sites included the undisturbed natural (background) soils (at three sites, under the herbaceous meadow vegetation; at one (Verkhopen'e) site, under the forest) and the plowed analogues of these soils of different ages. We attempted to find the appropriate plots in close proximity to one another, with due account for the similarity of the relief conditions and parent materials. Thus, we suppose that the main factor of changes in the soils of such agrochronosequences was the age of their agricultural use. However, we should take into account that the results obtained in our study reflect not only the influence of the duration (age) of tillage on the soil properties but also the influence of changes in agrotechnologies applied on these plots. It is probable that the strong impact of heavy machines and moldboard plowing during the last 70-80 years could erase and level the differences in the soil properties on the plots cultivated for a long (>100 years) time and the plots that have been involved in regular plowing for a shorter ( $<100$ years) period.
Large $(1.2 \times 2 \mathrm{~m})$ and deep (up to $2 \mathrm{~m}$ ) soil pits were examined on each of the plots. The morphological description of the soil profiles was accompanied by morphometric measurements (depths of genetic horizons and depth of effervescence) and soil sampling from the genetic horizons and from given depths (each $10 \mathrm{~cm}$ ) for the purpose of more accurate comparison of the profiles.

In 2011-2012, the Verkhopen'e and Yur'evka sites were studied in the spring (at the end of April) and, because of weather conditions, only one soil pit was examined on each of the selected plots. The Zhimolostnoe and Safonovka sites were investigated in the spring and summer of 2012 and 2013. Each of the plots was characterized by two soil pits spaced at 5$10 \mathrm{~m}$ apart from one another. Data on the soil properties for these plots represent averaged values for these pairs of soil pits.

To avoid inaccuracy in the identification of the plots and to be sure in the homogeneity of soil textures and parent materials, two plots characterizing midterm members of the agrochronosequence (140 and 200 years of plowing) at the Zhimolostnoe site had to be excluded from the further analysis, as they did not meet these criteria.

As a result, the following agrochronosequences were distinguished at the studied sites:

-Verkhopen'e: background soil-90-year-old plowland-120-year-old plowland-240-year-old plowland;

-Safonovka: background soil-140-year-old plowland-160-year-old plowland-230-year-old plowland;

-Zhimolostnoe: background soil-100-year-old plowland-240-year-old plowland;

-Yur'evka: background soil-16-year-old plowland-100-year-old plowland-240-year-old plowland.

The soil bulk density was determined via soil sampling with steel rings of fixed volume in triplicate for all the sampled soil profiles. Particle-size distribution was determined by the pipette method with sodium pyrophosphate pretreatment. Aggregate-size distribution was determined by the dry sifting method according to Savvinov.

The organic carbon content was determined by Tyurin's (wet combustion) method according to State Standard (GOST) 26213-91. The carbon of carbonates was determined by the manometric method $1 \mathrm{~h}$ after the beginning of the reaction of the soil samples with $10 \% \mathrm{HCl}$ added in excess to the vessels with rubber stoppers.

Thin sections from undisturbed soil samples were prepared in the laboratory of the Geological Faculty of Moscow State University. They were studied an optical Carl Zeiss HBO 50 microscope in the collective use center of the Institute of Physicochemical and Biological Problems of Soil Science in Pushchino. Data on the microfabrics of genetic horizons of cher- 


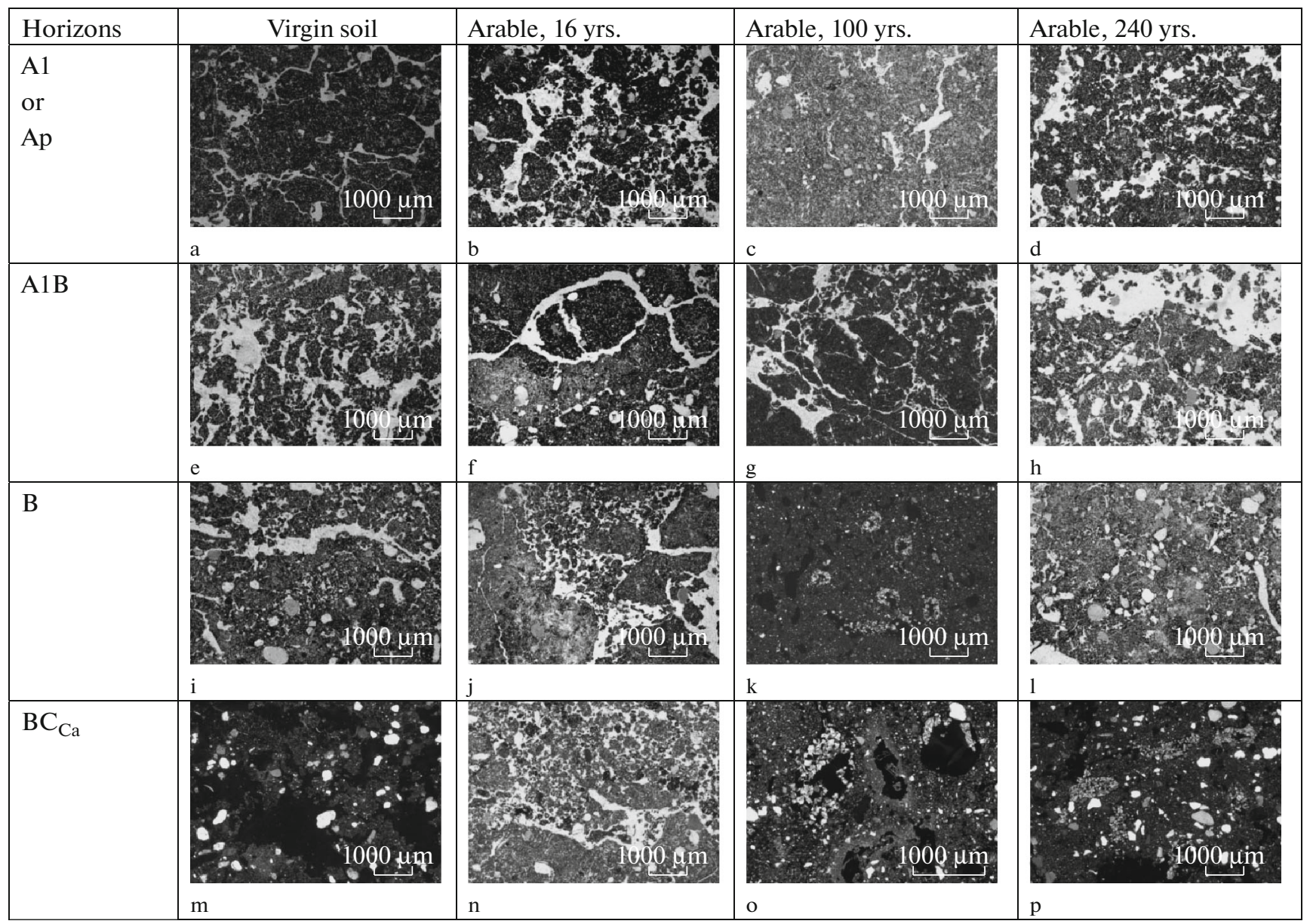

Fig. 2. Microfabrics of the horizons of virgin and arable chernozems of the agrochronosequence at the Yur'evka site. Photos k, $\mathrm{m}, \mathrm{o}$, and $\mathrm{p}, \mathrm{N} \mathrm{X}$; other photos, N II.

nozem from one of the studied agrochronosequences are presented in Fig. 2.

The ${ }^{14} \mathrm{C}$ age of humus and soil carbonates from different horizons of agrochernozems at the Zhimolostnoe and Safonovka chronosequences were obtained in the Radiocarbon Laboratory in Kiev.

\section{RESULTS AND DISCUSSION}

The results of the morphometric and laboratory analyses of the soil profiles are given in Tables 2-5.

A comparison of the background (virgin) and arable soils of the studied agrochronosequences demonstrates a tendency for a decrease in the thickness of the humus layer (A1 + A1B horizons of virgin chernozems and Ap + A1 + A1B horizons of plowed chernozems) with increase in the duration of the soil plowing (Table 2). The average value of this decrease in 200 years of the soil plowing for all the plots reaches $11.1 \mathrm{~cm}$. The mean arithmetic values (in each sample $n=90)$ of the total thickness of the A1 (Ap + A1) and A1B horizons of the studied soils are as fol- lows: $87.3 \pm 1 \mathrm{~cm}$ in the background chernozems, $82.7 \pm 1.3 \mathrm{~cm}$ in the chernozems cultivated for 90 140 years, and $76.2 \pm 1.2 \mathrm{~cm}$ in the chernozems cultivated for 230-240 years.

The decrease in the thickness of the humus layer of arable soils on level interfluves in the forest-steppe and steppe zones of Eastern Europe is usually interpreted as an evidence for the prevalence of water erosion over the rate of quasiclimax pedogenesis with due account for the agrotechnogenic soil compaction $[1,15]$. There is also an opinion about continuous windblowing of fine particles from the surface of tilled soils in the steppe zone [36].

In our point of view, this decrease is mainly related to the soil compaction. Our calculations show that the changes in the soil bulk density in the upper $20 \mathrm{~cm}$ (plow horizon) follow the exponential law; the intensity of soil compaction decreases after 100 years of the soil plowing. In that period, the soil bulk density increases from 0.9 to $1.15 \mathrm{~g} / \mathrm{cm}^{3}$ with an average rate of $0.02 \mathrm{~g} / \mathrm{cm}^{3}$ per decade. In the layer of $20-40 \mathrm{~cm}$ (the lower part of the plow layer, including the plowpan), 
Table 2. Statistical characteristics of the thickness $(\mathrm{cm})$ of humus horizons and humus layers $(\mathrm{cm})$ in the virgin and arable chernozems $(n=90)$

\begin{tabular}{|c|c|c|c|c|}
\hline Horizon & Lim & $X \pm \delta_{X}$ & $\delta$ & $V, \%$ \\
\hline \multicolumn{5}{|c|}{ Virgin chernozems } \\
\hline \multirow{2}{*}{$\begin{array}{l}\mathrm{A} 1 \\
\mathrm{~A} 1+\mathrm{A} 1 \mathrm{~B}\end{array}$} & $37-70$ & $55.4 \pm 0.9$ & 8.91 & 16.1 \\
\hline & $72-111$ & $87.3 \pm 1.0$ & 9.04 & 10.4 \\
\hline \multicolumn{5}{|c|}{ Arable chernozems, $90-140$ yrs. } \\
\hline \multirow{2}{*}{$\begin{array}{l}\mathrm{A} 1 \\
\mathrm{~A} 1+\mathrm{A} 1 \mathrm{~B}\end{array}$} & $38-74$ & $56.0 \pm 0.9$ & 8.15 & 14.6 \\
\hline & $57-109$ & $82.7 \pm 1.3$ & 12.21 & 14.8 \\
\hline \multicolumn{5}{|c|}{ Arable chernozems, $230-240$ yrs. } \\
\hline \multirow{2}{*}{$\begin{array}{l}\mathrm{A} 1 \\
\mathrm{~A} 1+\mathrm{A} 1 \mathrm{~B}\end{array}$} & $22-64$ & $42.3 \pm 1.1$ & 10.23 & 24.2 \\
\hline & $55-95$ & $76.2 \pm 1.2$ & 11.67 & 15.3 \\
\hline
\end{tabular}

Lim—-the range between minimum and maximum values, $X \pm \delta_{X}$-mean arithmetic and error of the mean, $\delta$-standard deviation, and $V$-coefficient of variation.

an increase in the bulk density follows the linear law. In 240 years, bulk density of this layer increases from $0.98 \mathrm{~g} / \mathrm{cm}^{3}$ in the virgin chernozems to $1.22 \mathrm{~g} / \mathrm{cm}^{3}$ in the old-cultivated chernozems with the average rate of $0.01 \mathrm{~g} / \mathrm{cm}^{3}$ per decade. The overall increase in the bulk density in the layers of $0-20$ and $0-40 \mathrm{~cm}$ in 240 years is approximately the same: 0.25 and $0.24 \mathrm{~g} / \mathrm{cm}^{3}$, respectively (Fig. 3). These changes in the bulk density are equivalent to the reduction of the thickness of the upper $50-\mathrm{cm}$ layer of virgin chernozems by $10.4 \mathrm{~cm}$ in 240 years, or $4.3 \mathrm{~cm}$ per 100 years (provided that no loss of the soil mass takes place in the plowed soils). In turn, this value is very close to the established difference between the thickness of the humus layer in the virgin and old-arable chernozems $(11 \mathrm{~cm})$. Therefore, we argue that the soil compaction is the major factor of a decrease in the thickness of the humus layer in the plowed chernozems.

It should be noted that during the investigated period of the soil tillage, changes in the thickness of the humus horizon of plowed chernozems $(\mathrm{Ap}+\mathrm{A} 1)$, in contrast to changes in the total thickness of the humus layer $(\mathrm{Ap}+\mathrm{A} 1+\mathrm{A} 1 \mathrm{~B})$ had a nonlinear character. According to averaged data on all the studied chronosequences, they were statistically insignificant during the first 90-140 years of tillage and considerable (a decrease by $13-14 \mathrm{~cm}$ ) in the period from 90140 to 230-240 years of plowing (Table 2). We suppose that the lower boundary of the A1B horizon layer was determined more exactly and accurately (because of the color contrast between this dark-colored horizon and the underlying pale yellow B horizon) than the boundary between the A1 and A1B horizons with gradual color changes. We also admit the possibility of more active zooturbation of the arable layer at the interface between the $\mathrm{A} 1$ and $\mathrm{A} 1 \mathrm{~B}$ horizons than that at the interface between the A1B and B horizons, which could also affect the accuracy of determination of the boundaries between the considered horizons.

Data on the depth of carbonates (depth of effervescence) in the studied soils are presented in Table 3 . It can be seen that the rise of carbonates by about $23 \mathrm{~cm}$ against the initial level took place in the first 90140 years of plowing. In the following years (90(140)-230(240) years), the upper boundary of carbonates descended to the initial level, i.e., their leaching took place.

Table 3. Statistical characteristics of the depth of effervescence $(\mathrm{cm})$ in the virgin and arable chernozems $(n=90)$

\begin{tabular}{l|c|c|c|c}
\hline Age of tillage, years & $\operatorname{Lim}$ & $X \pm \delta_{X}$ & $\delta$ & $V, \%$ \\
\hline 0 (virgin chernozems) & $60-154$ & $93.4 \pm 2.3$ & 21.49 & 23.0 \\
$90-140$ & $50-100$ & $70.4 \pm 1.5$ & 14.61 & 20.8 \\
$230-240$ & $112-125$ & $90.8 \pm 3.3$ & 31.06 & 34.2 \\
\hline
\end{tabular}

Table 4. Area of visually determined tunnels of mole rats $(\%$ of the section area) in chernozems of the studied agrochronosequences (averaged for all the sites; areas of tunnel sections on front walls of the pits were determined from schematic drawings of frontal walls of the soil pits)

\begin{tabular}{l|c|c|c}
\hline \multirow{2}{*}{ Layer, cm } & \multicolumn{3}{|c}{ Age of plowland, yrs. } \\
\cline { 2 - 4 } & $0(n=6)$ & $90-140(n=7)$ & $230-240(n=6)$ \\
\hline $0-50$ & 6.88 & 8.65 & 26.55 \\
$50-100$ & 45.67 & 66.19 & 77.44 \\
$100-150$ & 30.90 & 34.70 & 41.87 \\
$150-200$ & 8.83 & 12.64 & 18.75 \\
$0-200$ & 23.07 & 30.55 & 41.15 \\
\hline
\end{tabular}

$n$ is the number of the investigated soil pits. 
Table 5. Humus pools $(\mathrm{t} / \mathrm{ha})$ in chernozems of the studied agrochronosequences

\begin{tabular}{|c|c|c|c|c|}
\hline \multirow{2}{*}{ Depth, $\mathrm{cm}$} & \multicolumn{4}{|c|}{ Areas } \\
\hline & $\begin{array}{l}\text { under natural } \\
\text { vegetation }\end{array}$ & \multicolumn{3}{|c|}{ arable plots of different ages } \\
\hline \multicolumn{5}{|c|}{ Verkhopen'e } \\
\hline & Forest & \multicolumn{3}{|c|}{ Arable } \\
\hline & & 90 yrs. & 120 yrs. & 240 yrs. \\
\hline $0-10$ & 85.8 & 65.0 & 63.7 & 61.0 \\
\hline $10-20$ & 81.9 & 74.0 & 70.1 & 66.2 \\
\hline $20-30$ & 67.6 & 67.8 & 64.5 & 61.4 \\
\hline $30-40$ & 57.6 & 59.5 & 56.2 & 50.7 \\
\hline $40-50$ & 52.6 & 46.7 & 47.0 & 38.2 \\
\hline $50-60$ & 43.6 & 39.9 & 39.6 & 33.3 \\
\hline $60-70$ & 35.0 & 34.9 & 33.2 & 31.4 \\
\hline $70-80$ & 30.4 & 30.2 & 29.2 & 31.0 \\
\hline $80-90$ & 20.79 & 28.7 & 28.5 & 26.5 \\
\hline $90-100$ & 20.5 & 25.0 & 23.5 & 24.1 \\
\hline $0-50$ & 345.5 & 313.0 & 301.5 & 277.5 \\
\hline $50-100$ & 150.3 & 158.7 & 154.0 & 146.3 \\
\hline $0-100$ & 495.8 & 471.7 & 455.5 & 423.8 \\
\hline \multicolumn{5}{|c|}{ Safonovka } \\
\hline & \multirow{2}{*}{ Virgin land } & \multicolumn{3}{|c|}{ Arable } \\
\hline & & 140 yrs. & 160 yrs. & 230 yrs. \\
\hline $0-10$ & 91.38 & 70.68 & 64.57 & 62.85 \\
\hline $10-20$ & 87.41 & 74.13 & 74.72 & 66.32 \\
\hline $20-30$ & 76.99 & 69.84 & 68.17 & 66.89 \\
\hline $30-40$ & 65.84 & 53.45 & 60.73 & 58.20 \\
\hline $40-50$ & 55.05 & 47.93 & 51.11 & 46.66 \\
\hline $50-60$ & 46.85 & 43.93 & 44.93 & 43.12 \\
\hline $60-70$ & 37.23 & 37.44 & 35.59 & 38.27 \\
\hline $70-80$ & 35.04 & 33.89 & 33.49 & 36.19 \\
\hline $80-90$ & 30.52 & 31.34 & 29.60 & 30.70 \\
\hline $90-100$ & 23.89 & 28.01 & 27.10 & 27.00 \\
\hline $0-50$ & 376.67 & 316.03 & 319.30 & 300.92 \\
\hline $50-100$ & 173.53 & 174.61 & 170.71 & 175.28 \\
\hline $0-100$ & 550.20 & 490.64 & 490.01 & 476.20 \\
\hline \multicolumn{5}{|c|}{ Yur'evka } \\
\hline & \multirow[t]{2}{*}{ Virgin land } & \multicolumn{3}{|c|}{ Arable } \\
\hline & & 16 yrs. & 100 yrs. & 240 yrs. \\
\hline $0-10$ & 77.0 & 64.3 & 59.5 & 54.4 \\
\hline $10-20$ & 76.8 & 63.7 & 58.1 & 55.0 \\
\hline $20-30$ & 63.5 & 63.7 & 58.5 & 57.7 \\
\hline $30-40$ & 56.7 & 54.9 & 58.5 & 58.1 \\
\hline $40-50$ & 49.6 & 51.1 & 55.1 & 39.1 \\
\hline $50-60$ & 47.2 & 48.8 & 50.3 & 31.5 \\
\hline
\end{tabular}


Table 5. (Contd.)

\begin{tabular}{|c|c|c|c|c|}
\hline \multirow[b]{2}{*}{ Depth, cm } & \multicolumn{4}{|c|}{ Areas } \\
\hline & $\begin{array}{l}\text { under natural } \\
\text { vegetation }\end{array}$ & \multicolumn{3}{|c|}{ arable plots of different ages } \\
\hline $60-70$ & 37.2 & 39.3 & 45.8 & 30.0 \\
\hline $70-80$ & 35.2 & 35.9 & 36.9 & 21.3 \\
\hline $80-90$ & 33.5 & 33.7 & 30.6 & 11.0 \\
\hline $90-100$ & 23.2 & 23.4 & 18.5 & 10.4 \\
\hline $0-50$ & 323.6 & 297.7 & 289.7 & 264.3 \\
\hline $50-100$ & 176.3 & 181.1 & 182.1 & 104.2 \\
\hline $0-100$ & 499.9 & 478.8 & 471.8 & 368.5 \\
\hline \multicolumn{5}{|c|}{ Zhimolostnoe } \\
\hline & Virgin land & Arable, 100 yrs. & \multicolumn{2}{|c|}{ Arable, 240 yrs. } \\
\hline $0-10$ & 64.8 & 54.7 & \multicolumn{2}{|c|}{47.9} \\
\hline $10-20$ & 63.6 & 55.5 & \multicolumn{2}{|c|}{57.7} \\
\hline $20-30$ & 62.9 & 53.3 & \multicolumn{2}{|c|}{47.8} \\
\hline $30-40$ & 54.0 & 45.0 & \multicolumn{2}{|c|}{39.0} \\
\hline $40-50$ & 45.2 & 37.1 & \multicolumn{2}{|c|}{28.3} \\
\hline $50-60$ & 31.2 & 26.5 & \multicolumn{2}{|c|}{26.2} \\
\hline $60-70$ & 23.1 & 23.4 & \multicolumn{2}{|c|}{21.3} \\
\hline $70-80$ & 15.9 & 16.4 & \multicolumn{2}{|c|}{9.3} \\
\hline $80-90$ & 14.0 & 17.4 & \multicolumn{2}{|c|}{7.9} \\
\hline $90-100$ & 9.3 & 11.5 & \multicolumn{2}{|c|}{5.0} \\
\hline $0-50$ & 290.5 & 245.6 & \multicolumn{2}{|c|}{220.7} \\
\hline $50-100$ & 93.5 & 95.3 & \multicolumn{2}{|c|}{69.7} \\
\hline $0-100$ & 384.0 & 340.8 & \multicolumn{2}{|c|}{290.4} \\
\hline
\end{tabular}

The observed tendency for the opposite behavior of the upper part of the carbonate profile of chernozems in the forest-steppe of European Russia during the first 100 years of their plowing and in the subsequent period needs special studies.

One of the most important characteristics of the physical properties of chernozems is the particle-size distribution in the upper horizons and in the entire profile. The studied soils are loamy soils with variations from silt loamy to clay loamy on different plots (Table 1). The spatial trends of changes in the clay content along the soil profiles down to $1 \mathrm{~m}$ are shown in Fig. 4. In general, it can be seen that the arable chernozems are richer in the clay fraction in comparison with the background (virgin) chernozems at the Verkhopen'e, Safonovka, and Yur'evka sites; the most significant accumulation of this fraction (by $8-10 \%$ ) was observed in the upper horizons down to $40-60 \mathrm{~cm}$.

The micromorphological analysis of soils studied at the Yur'evka site did not show any features (ironclay coatings) attesting to the migration of clay in the profiles of both virgin and arable chernozems (Fig. 2). Hence, the accumulation of clay under the plow layer can take place owing to the physical comminution of the soil particles; it is possible that the soil gleyzation enhances this process. The features of the soil overmoistening are clearly pronounced; these are ironmanganic concentrations and mottles and mottled color patterns under the plow layer (Figs. $2 \mathrm{f}$ and $2 \mathrm{~h}$ ) and in the B horizon of plowed soils (Figs. 2j and 2l).

A clear tendency for the accumulation of clay is observed in the first 100-150 years of tillage of the studied chernozems. Afterwards, the content of the clay fraction in the soil profiles somewhat decreases (Fig. 4). We suppose that the clay content in the arable chernozems reaches a quasiequilibrium with the new combination of the factors of soil formation related to tillage (first of all, with the new climatic conditions established in arable soils and the regular impact of tillage) in about 100-150 years of plowing.

In some studies, the phenomenon of agrolessivage (this term was coined by F.I. Kozlovskii) leading to the depletion of clay from the plow horizons and its accumulation in the lower horizons was noted [17, 40]. Besides, there are data on the possibility of argillization in arable forest-steppe chernozems under the 

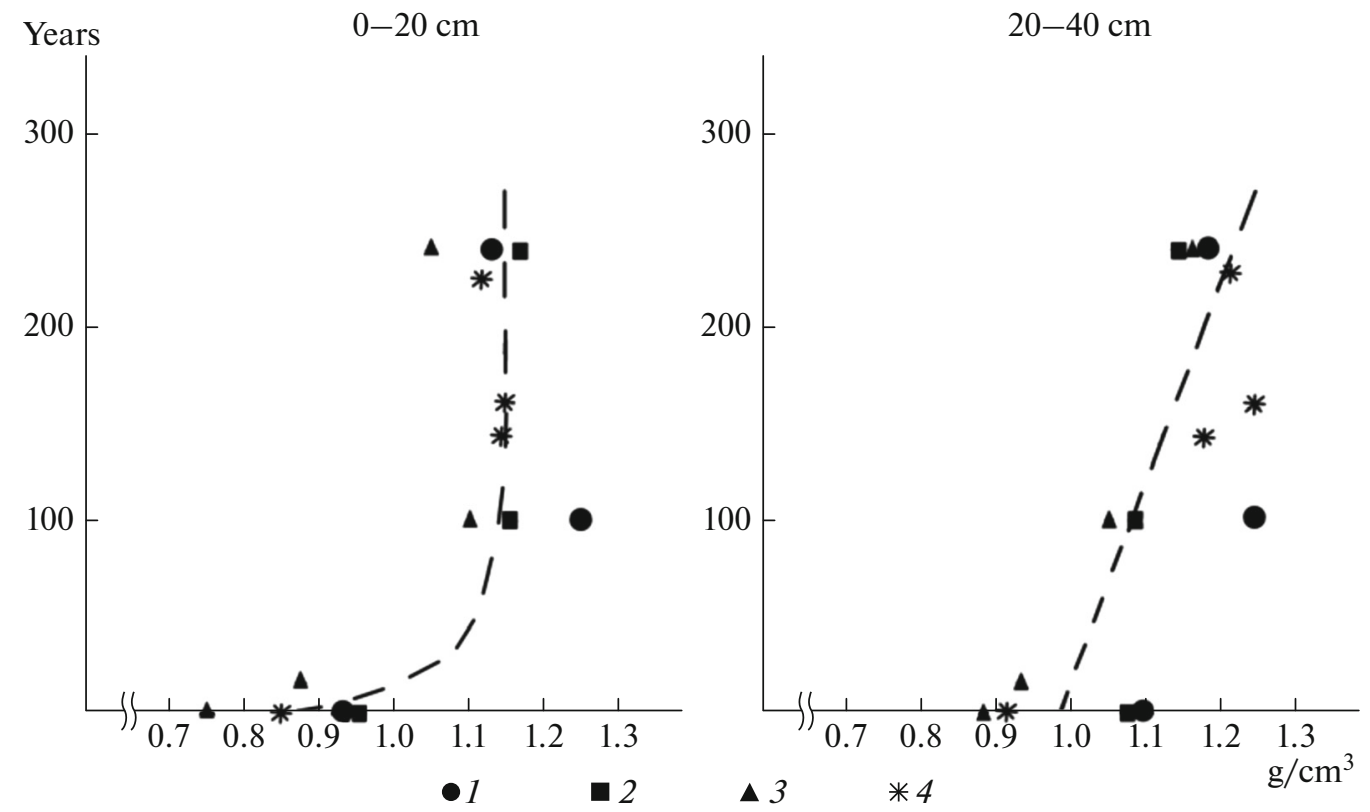

Fig. 3. Bulk density in the layers of $0-20$ and $20-40 \mathrm{~cm}$ in chernozems of the studied agrochronosequences.
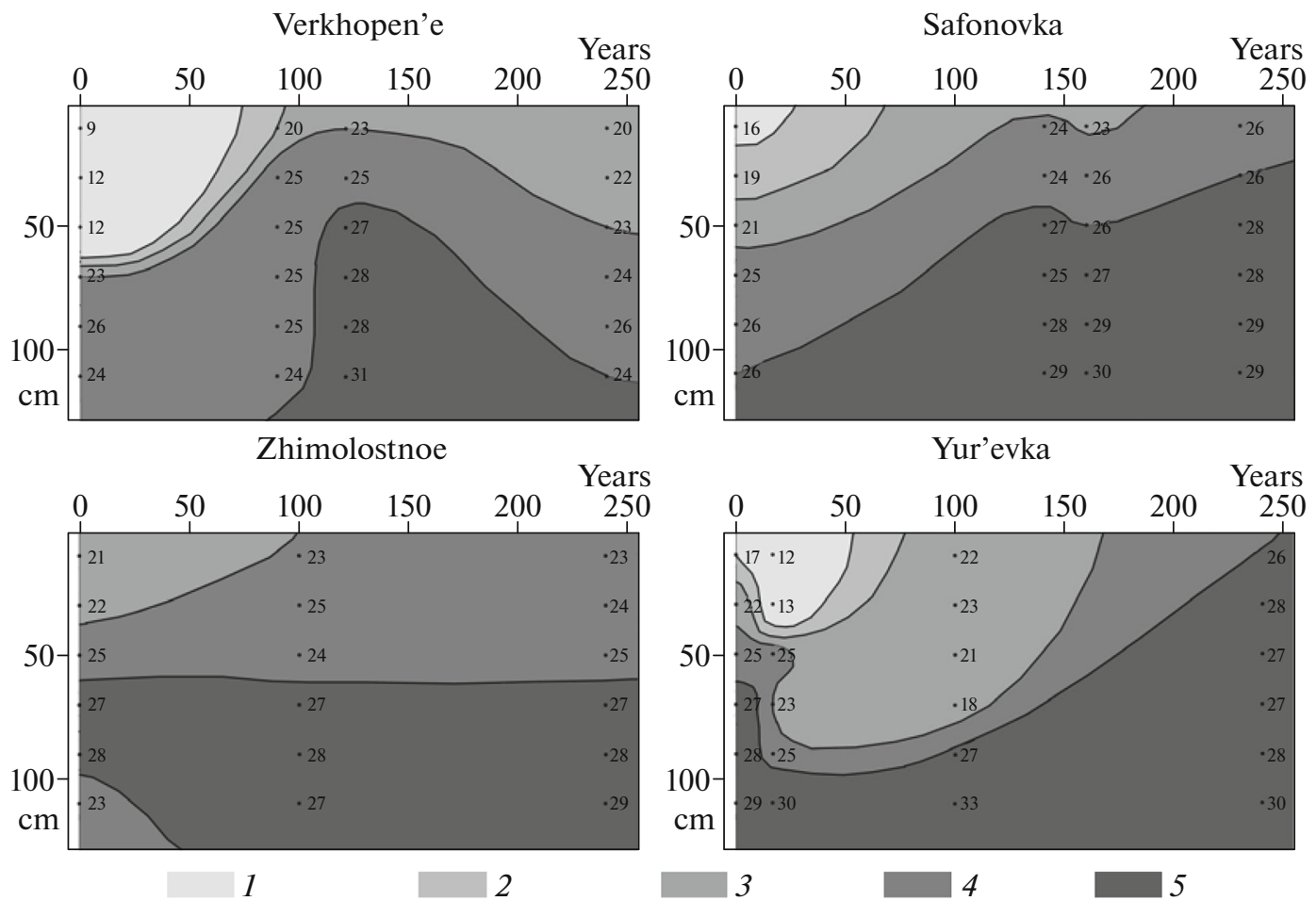

Fig. 4. Spatial changes in the clay content of chernozems of the studied agrochronosequences. The clay content, $\%$ : $(1)<17$, (2) $17-20$, (3) $20.1-23$, (4) $23.1-26$, and (5) $>26$.

impact of weathering and formation of secondary clay minerals $[1,9]$. According to our results, the second hypothesis seems to be more reasonable, though the nature of the formation of a heavier texture in the pro- files of arable soils remains uncertain and requires further studies. We suppose that the most probable set of processes leading to the accumulation of clay in the upper horizons of arable chernozems includes disag- 

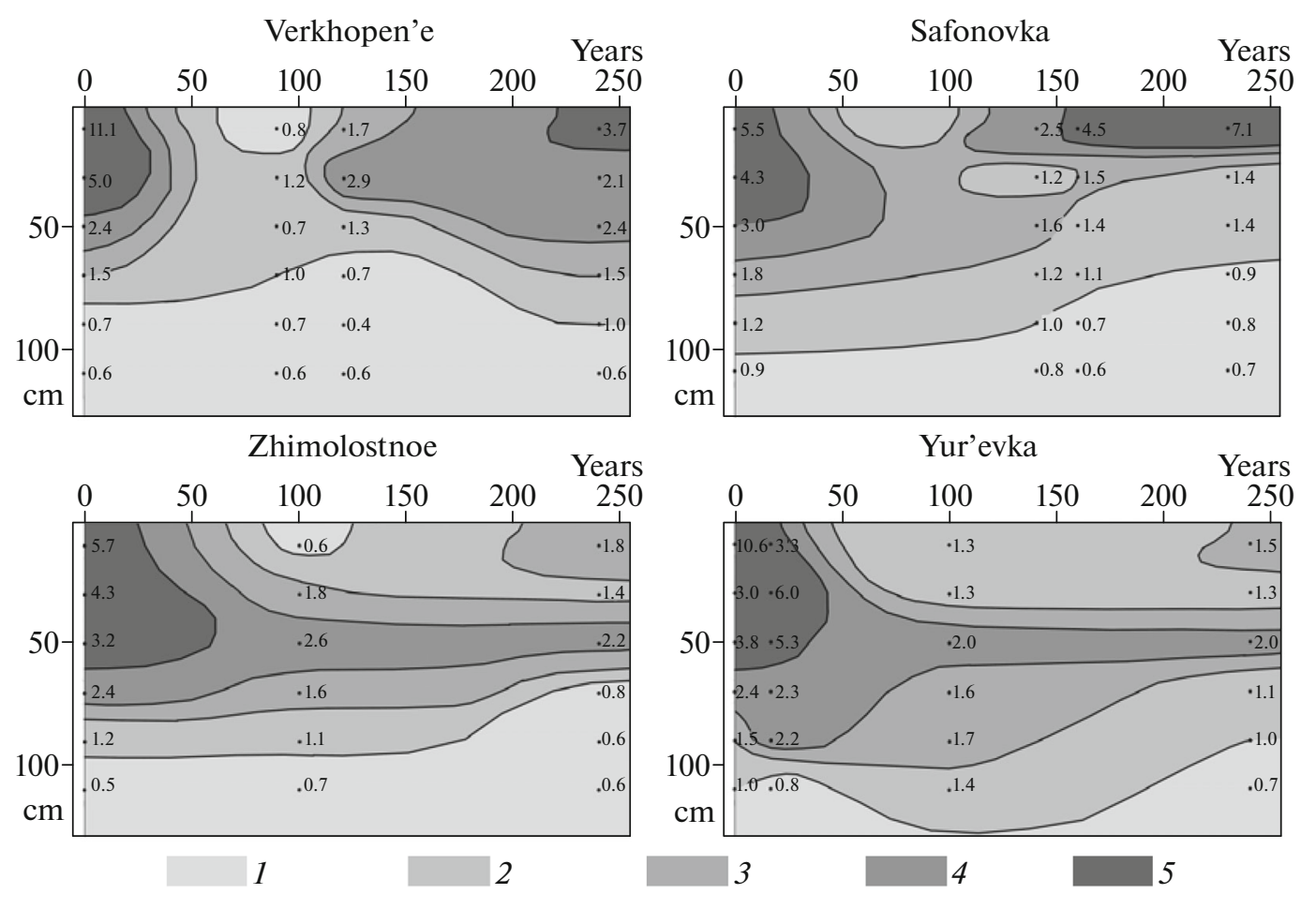

Fig. 5. Changes in the coefficient of aggregation along the profiles of chernozems at different stages of their agricultural development. Coefficient of aggregation: (1) $<1,(2) 1-1.5$, (3) $1.6-2.0$, (4) $2-3$, and (5) $>3$.

gregation of their structure of chernozems with the accumulation of microaggregates $(<0.1 \mathrm{~mm})$. The intensity of this process increases with time, which was indicated by Bruk [7].

The coefficient of aggregation of the chernozems is characterized by the similar pattern of its changes with time with an increase in the duration of plowing on each of the plots (Fig. 5).

Below the plow horizon, the zone with relatively high values of the coefficient of aggregation even in the old-arable soils can be distinguished. This can be explained by the redistribution of mobile organomineral compounds and humus with gluing properties in the soil profile. As a result, soil aggregates in the lower part of the A1 horizon and in the A1B horizon become enriched with these substances [5, 35]. The morphogenetic analysis of the soil profiles attests to the high activity of burrowers, particularly mole rats, in the studied agrochernozems. The area of the paths of mole rats on the walls of pits in the plowed soil is greater than that in the background soils (Table 4). We may also suppose that the formation of the zone enriched in the agronomically valuable soil aggregates under the plow layer is caused by the unfavorable conditions for the activity of burrowing animals in the plow layer. The animals tend to move into the deeper soil layers, where the loosening effect of their activity favors the soil aggregation. It is probable that a higher activity of burrowing animals (mainly, mole rats) in the old-ara- ble chernozems ( $>200$ years) results in some improvement of the structural state and the coefficient of aggregation even in the plow horizons.

The analysis of the activity of burrowers in the soils of studied agrochronosequences on the basis of data on the area of their tunnels shows that this area gradually increases with an increase in the duration of soil plowing in all the horizons of the soil profile, except for the upper $50 \mathrm{~cm}$. In the upper $50 \mathrm{~cm}$, some increase in the area of tunnels on the pit walls is seen in the oldest members (230-240 years) of the agrochronosequences. This can be interpreted in terms of the higher activity of burrowers in the period of the soil tillage by horse-pulled tools, or as an evidence for a continuous increase in the activity of burrowers in the plowed soils (as judged from the area of tunnels on the walls of the pits) with an increase in the duration of plowing.

Micromorphological data also confirm the intensified zoogenic mixing of the soil mass in the arable chernozems. The activity of mesofauna is most pronounced in the A1B horizon. The zoogenic pores contain flocks of humus, comminuted plant remains that have lost their cell structure, coprogenic aggregates, and microloci of zoogenic decompaction (Figs. $2 \mathrm{e}-2 \mathrm{~h}$ ); in the B horizon, calcified root cells can be seen in the soil mass transformed by burrowing animals (Figs. 2k, 2o, and 2p). Some features attesting to the activity of burrowing animals can be seen even in the deep $\mathrm{BC}$ and $\mathrm{C}$ horizons of arable 
chernozems (Fig. 2n), though they are absent at these depths in the virgin chernozems.

At all the chronosequences, certain stages in the transformation of the aggregate composition of the soils can be traced (Fig. 5). We distinguish between three major stages. During the first stage lasting for about 50-70 years after the beginning of tillage, the coefficient of aggregation of the soil mass in the upper meter decreases; this decrease is most pronounced in the upper $50 \mathrm{~cm}$ of the soil profiles. The second stage lasts within the time range from 50(70) to $150(180)$ years after the beginning of tillage. It is characterized by the lowest values of the coefficient of aggregation in the plow horizons and by insignificant changes of this coefficient in the deeper horizons. The third stage is characterized by a tendency for the rise of this coefficient in the plot horizon, which may be related to the enhanced zoogenic turbation of the upper part of the profile in the old-arable chernozems.

The behavior of organic matter in the chernozems of the studied chronosequences attracts special attention (Table 5). According to the micromorphological observations, the plow horizons of the chernozems differ from the Al horizon of the virgin soils by a greater number and diversity of plant residues at different degrees of decomposition; the particulate forms of organic matter are often confined to the mesofauna casts. In general, the humus-clayey plasma in the plow horizons loses its coherence; skeletal particles devoid of their humus coatings are present in the plow horizon (Figs, $2 b-2 d$ ). At the same time, the humusclayey plasma in the A1B horizon becomes darker in comparison with that in the virgin chernozems. This may attest to a higher intensity of the vertical translocation of humus in the profiles of plowed chernozems [22], though we did not find any clear micromorphological indications of humus illuviation process.

On each of the investigated sites, dehumification of the soil profiles in the course of plowing could be clearly observed. The initial stage (about 100 years of plowing) is characterized by the considerable loss of humus from the plow horizon and by some accumulation of humus in the middle-profile horizons. This can be clearly seen from data on humus storages in the plowed and virgin chernozems (Table 5). This is a wellknown fact that has been described in scientific literature. Some scientists point to the possibility of the migration of mobile humus into the subsoil [5, 33, 35]. However, this phenomenon is not confirmed by the micromorphological observations in the studied agrochronosequences. Some authors argue that the material from the upper humus horizon can fill the network of deep fissures appearing in the arable steppe foreststeppe and steppe chernozems [16, 38]. Indeed, we observed desiccation fissures filled with the humus material in the plowed chernozems. In our opinion, this mechanism, along with the activity of macro- and mesofauna, is the major factor of the enrichment of the soil under the plow horizon with humus substances in the recently cultivated chernozems. We argue that the intensity of the zoogenic activity in the plowed chernozems and its impact on the soil properties were underestimated in the earlier studies [43].

The further cultivation of chernozems ( $>100$ years) is accompanied by a decrease in the intensity of dehumification of the plow horizon and by the disappearance of the maximum store of humus under the plow horizon; dehumification processes are evenly developed in the entire profiles of these chernozems.

Figure 6 shows an integral (for all the plots) scheme of temporal changes in the pools of humus in the arable chernozems for the layers of $0-30,0-50$ and $0-$ $100 \mathrm{~cm}$ in percent of the initial pools in the virgin chernozems. For the layers of $0-30$ and $0-50 \mathrm{~cm}$, these changes are very similar for all the plots and can be described by an exponential curve that can be simplified in the form of two linear trends reflecting the initial (40-50 years) stage of the quick loss of humus and the subsequent stage of the slow loss of humus. The dehumification of the entire 1-m-deep layer within 240 years of cultivation follows the linear trend without its separation into certain stages.

In the layer of $0-30 \mathrm{~cm}$, the intensity of the loss of humus in the initial (40-50 years) stage in the studied soils varies from 0.44 to $0.82 \mathrm{t} / \mathrm{ha}$ per year $(0.61 \mathrm{t} /$ ha per year on the average). During the second stage (the next 200 years), the rate of humus loss from this layer decreases to $0.07-0.12 \mathrm{t} /$ ha per year ( $0.09 \mathrm{t} /$ ha per year on the average), which is almost seven times lower than that during the first stage. The loss of humus from the upper soil meter during the entire studied period (240 years) on the studied plots proceeds with the average rates of 0.3 to $0.55 \mathrm{t} / \mathrm{ha}$ per year $(0.41 \mathrm{t} / \mathrm{ha}$ per year on the average $)$. The overall decrease in the humus pools during 240 years of plowing comprises $45 \mathrm{t} / \mathrm{ha}$ ( $21.4 \%$ of the initial store) in the layer of $0-30 \mathrm{~cm}, 67 \mathrm{t} / \mathrm{ha}(21 \%)$ in the layer of $0-50 \mathrm{~cm}$, and $100 \mathrm{t} / \mathrm{ha}(22 \%)$ in the layer of $0-$ $100 \mathrm{~cm}$. Note that the significant loss of humus $(55 \mathrm{t} / \mathrm{ha})$ takes place in the layer of $30-100 \mathrm{~cm}$; this loss is not directly related to the removal of the soil carbon with harvest.

In the earlier studies [2, 8, 10, 23, 30, 32, 34, 35], the major attention was paid to the humus content rather than to the humus store in the plowed chernozems of different ages. As noted by Orlov with coauthors [26], this could result in the erroneous estimation of the true loss of humus from the arable chernozems. We studied long chronosequences of arable chernozems (there are no data on such long chronosequences in previously published works) and analyzed not only data on the humus content $(\%)$ in the studied soils but also on the bulk soil density. Thus, we could use a more objective criterion-the store of humus-to judge the loss of humus from the plowed chernozems. 
New data were also obtained on the store of carbonates in the arable chernozems of different ages. As seen from Table 6 , the accumulation of carbonates (some calcification) in the soil profiles is observed during the initial (100 years) period of the soil cultivation. Then, the reserves of carbonates in the 2-m-deep soil layer tend to decrease, which attests to the leaching of carbonates beyond the soil profile, As for the carbonates store in the mass of chernozems with different time of tillage. In other words, the initial period of calcification of the arable chernozems is replaced by the period of their decalcification, which reflects the complexity of pedogenic processes and their stadial changes with time in the course of the long-term cultivation of chernozems.

The results of the radiocarbon dating of humus and carbonates in the studied soils are shown in Table 7. Their graphical representation for the soils of the Safonovka site is given in Fig. 7.

The ${ }^{14} \mathrm{C}$-dates of humus in each of the investigated layers $(10-20,30-40$, and $50-60 \mathrm{~cm})$ increase with an increase in the duration of the soil plowing, which is quite reasonable, because the agrogenic dehumification of the soils proceeds mainly at the expense of the labile (and young) humus. This is true not only for the upper but also for the deeper horizons. It is interesting that the ${ }^{14} \mathrm{C}$-dates of humus from the layer of 30-40 are approximately the same in all the soils of the studied agrochronosequence (with a slight tendency for their increase in the old-arable chernozems). In the horizons above and under this layer, the radiocarbon age of humus in the arable chernozems is higher than that in the virgin soil (Fig. 7). As for this layer, it may be enriched in the "young" humus substances admixed into it by the zoogenic turbation and/or through the network of desiccation fissures. In other words, the dehumification in this middle-profile layer is partly compensated for by the input of "fresh" organic matter point.

The changes in the radiocarbon age of pedogenic carbonates in the layers of $60-70$ and $130-140 \mathrm{~cm}$ attest to the stadial character of the agrogenic evolution of the chernozems. The first stage lasting for about 140-160 years of regular tillage is characterized by the pronounced rejuvenation of the carbonates in this layer. Afterwards, the radiocarbon age of pedogenic carbonates increases up to the levels typical of the background (virgin) soil.

The radiocarbon age of carbonates at the level of their upper boundary $(60-70(80) \mathrm{cm})$ remains unchanged during the first $100-150$ years and then increases (Table 7, Safonovka and Zhimolostnoe sites). Thus, old-arable chernozems are characterized by a tendency for the ascending migration of ancient carbonates from the deep soil layers; the same phenomenon was earlier described for the arable gray forest soils in the investigated region [37, 39, 42].

Micromorphological data do not indicate the presence of carbonate coatings and infillings in the mid-
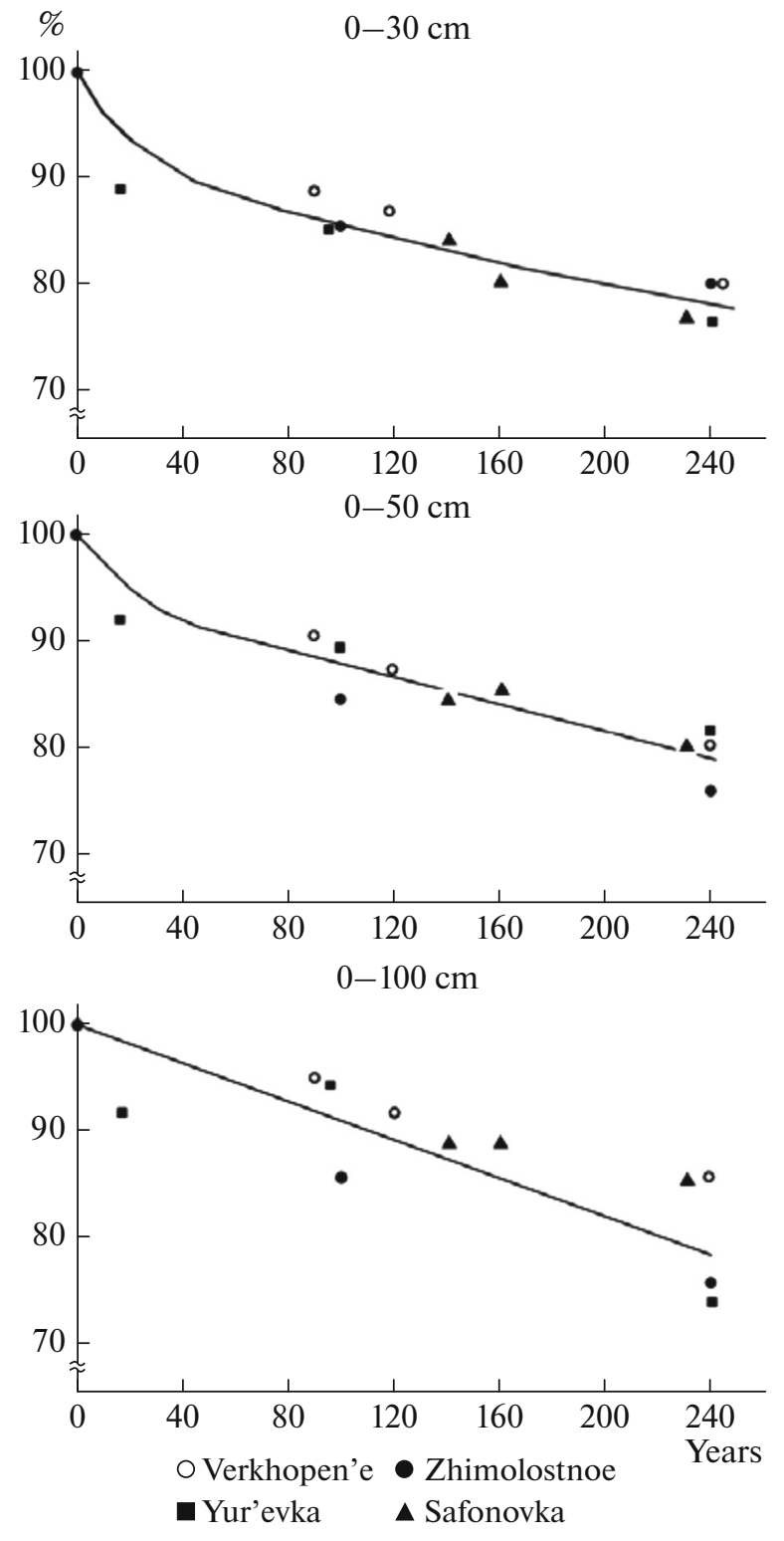

Fig. 6. Temporal changes in the humus pool of arable chernozems in the forest-steppe zone of Belgorod oblast, \% of the initial pool.

dle-profile horizons of the plowed chernozems. Various biogenic carbonate pedofeatures predominate in these horizons. These are calcified root cells in pores and disperse calcite grains that represent the remains of former calcified root cells disturbed and mixed by the mesofauna. (Figs. 2j-21). It is probable that the biogenic calcification is the main factor of the rejuvenation of ${ }^{14} \mathrm{C}$-age of carbonates in the chernozems plowed for 100-150 years, in which carbonates appear in a higher amount and shallower depth than those in the virgin chernozems. Indeed, the formation of biogenic calcite assumes its recrystallization and exchange with the "fresh" $\mathrm{CO}_{2}$ in the soil profile, and, thus, the rejuvenation of the carbonates. It is probable 
Table 6. Pools of $\mathrm{CaCO}_{3}(\mathrm{t} / \mathrm{ha})$ in chernozems of the studied agrochronosequences

\begin{tabular}{|c|c|c|c|c|}
\hline \multirow{2}{*}{ Depth, cm } & \multicolumn{4}{|c|}{ Areas } \\
\hline & $\begin{array}{l}\text { under natural } \\
\text { vegetation }\end{array}$ & \multicolumn{3}{|c|}{ arable plots of different ages } \\
\hline \multicolumn{5}{|c|}{ Verkhopen'e } \\
\hline & \multirow{2}{*}{ forest } & \multicolumn{3}{|c|}{ arable } \\
\hline & & 90 yrs. & 120 yrs. & 240 yrs. \\
\hline $0-20$ & 0 & $\mathrm{~N} / \mathrm{D}$ & 0 & 0 \\
\hline $20-40$ & 0 & $"$ & 0 & 0 \\
\hline $40-60$ & 0 & $"$ & 0 & 0 \\
\hline $60-80$ & 0 & $"$ & 0 & 0 \\
\hline $80-100$ & 25.4 & $"$ & 52.8 & 0 \\
\hline $100-120$ & 78.1 & $"$ & 162.5 & 0 \\
\hline $120-140$ & 99.3 & $"$ & 167.0 & 108.0 \\
\hline $140-160$ & 121.5 & $"$ & 140.0 & 143.9 \\
\hline $160-180$ & 133 & $"$ & 124.0 & 180.8 \\
\hline $180-200$ & 77.8 & $"$ & 115.3 & 197.5 \\
\hline $0-100$ & 25.4 & $"$ & 52.8 & 0 \\
\hline $100-200$ & 509.7 & $"$ & 708.8 & 630.2 \\
\hline $0-200$ & 535.1 & $"$ & 761.6 & 630.2 \\
\hline \multicolumn{5}{|c|}{ Safonovka } \\
\hline & \multirow{2}{*}{ virgin land } & \multicolumn{3}{|c|}{ arable } \\
\hline & & 140 yrs. & 160 yrs. & 230 yrs. \\
\hline $0-20$ & 16.0 & 4.3 & 8.2 & 12.5 \\
\hline $20-40$ & 66.2 & 25.1 & 62.8 & 43.6 \\
\hline $40-60$ & 90.4 & 83.0 & 10.6 & 100.3 \\
\hline $60-80$ & 185.0 & 179.5 & 53.4 & 97.9 \\
\hline $80-100$ & 239.6 & 222.6 & 117.7 & 100.2 \\
\hline $100-120$ & 287.7 & 253.5 & 154.3 & 139.7 \\
\hline $120-140$ & 328.4 & 306.0 & 272.9 & 293.4 \\
\hline $140-160$ & 285.7 & 359.0 & 289.6 & 288.2 \\
\hline $160-180$ & 270.1 & 301.8 & 298.2 & 251.3 \\
\hline $180-200$ & 278.1 & 256.2 & 287.7 & 192.5 \\
\hline $0-100$ & 597.2 & 514.5 & 252.7 & 354.5 \\
\hline $100-200$ & 1450.0 & 1991 & 1302.7 & 1165.1 \\
\hline $0-200$ & 2047.2 & 2505.5 & 1555.4 & 1519.6 \\
\hline \multicolumn{5}{|c|}{ Yur'evka } \\
\hline & \multirow{2}{*}{ virgin land } & \multicolumn{3}{|c|}{ arable } \\
\hline & & 16 yrs. & 100 yrs. & 240 yrs. \\
\hline $0-20$ & 12.8 & 19.6 & 31.1 & 15.3 \\
\hline $20-40$ & 9.9 & 21.6 & 28.5 & 17.0 \\
\hline $40-60$ & 21.6 & 25.2 & 29.9 & 21.1 \\
\hline $60-80$ & 20.7 & 121.7 & 34.6 & 197.7 \\
\hline $80-100$ & 0 & 295.4 & 120.9 & 367.1 \\
\hline $100-120$ & 37.8 & 360.4 & 322.0 & 345.1 \\
\hline
\end{tabular}


Table 6. (Contd.)

\begin{tabular}{|c|c|c|c|c|}
\hline \multirow[b]{2}{*}{ Depth, cm } & \multicolumn{4}{|c|}{ Areas } \\
\hline & $\begin{array}{l}\text { under natural } \\
\text { vegetation }\end{array}$ & \multicolumn{3}{|c|}{ arable plots of different ages } \\
\hline $120-140$ & 273.2 & 504.3 & 457.3 & 265.1 \\
\hline $140-160$ & 433.4 & 574.8 & 473.4 & 148.2 \\
\hline $160-180$ & 493.0 & 437.2 & 457.0 & 143.8 \\
\hline $180-200$ & 510.0 & 443.1 & 409.5 & 204.9 \\
\hline $0-100$ & 65.0 & 483.5 & 245 & 618.2 \\
\hline $100-200$ & 1747.4 & 2319.8 & 2119.2 & 1107.0 \\
\hline $0-200$ & 1812.4 & 2803.3 & 2364.2 & 1725.2 \\
\hline \multicolumn{5}{|c|}{ Zhimolostnoe } \\
\hline & virgin land & arable, 100 yrs. & \multicolumn{2}{|c|}{ arable, $240 \mathrm{yrs}$. } \\
\hline $0-20$ & 8.1 & 7.9 & \multicolumn{2}{|c|}{3.6} \\
\hline $20-40$ & 7.3 & 8.4 & \multicolumn{2}{|c|}{4.8} \\
\hline $40-60$ & 9.7 & 9.9 & \multicolumn{2}{|c|}{10.6} \\
\hline $60-80$ & 79.5 & 338.6 & \multicolumn{2}{|c|}{16.3} \\
\hline $80-100$ & 267.7 & 386.8 & \multicolumn{2}{|c|}{126.2} \\
\hline $100-120$ & 173.6 & 386.8 & \multicolumn{2}{|c|}{216.4} \\
\hline $120-140$ & 118.4 & 224.2 & \multicolumn{2}{|c|}{253.7} \\
\hline $140-160$ & 45.8 & 26.6 & \multicolumn{2}{|c|}{216} \\
\hline $160-180$ & 21.3 & 26.1 & \multicolumn{2}{|c|}{114.6} \\
\hline $180-200$ & 40.7 & 4.1 & \multicolumn{2}{|c|}{75.2} \\
\hline $0-100$ & 372.3 & 751.6 & \multicolumn{2}{|c|}{161.5} \\
\hline $100-200$ & 399.8 & 667.8 & \multicolumn{2}{|c|}{875.9} \\
\hline $0-200$ & 772.1 & 1419.4 & \multicolumn{2}{|c|}{1037.4} \\
\hline
\end{tabular}

that this process becomes slowed down or stops in the old-arable ( $>200$ years) chernozems.

\section{CONCLUSIONS}

The approach applied in our study of the agrochronosequences of chernozems included a set of methods and allowed us to obtain a more comprehensive picture of temporal changes in these soils in the course of their long-term cultivation.

The bulk density of the plow horizon $(0-20 \mathrm{~cm})$ of chernozems considerably increases during the first century of their plowing; then, the increase in the bulk density slows down. The same pattern of temporal changes is observed for the clay content in the upper part of the profile of arable chernozems: a significant increase in the first 100 years and stabilization in the subsequent period. The first stage of intense degradation of the structural state of arable chernozems lasts for about $50-70$ years. The second stage is characterized by the minimal values of the coefficient of aggregation in the plow horizon and its maximal values in the deeper part of the humus layer; it is observed in the period from 50(70) to $160(180)$ years of tillage. The third stage is characterized by a gradual increase in the values of the coefficient of aggregation in the upper part of the profile (160(180)-230(240) years).

In terms of the soil fertility, dehumification of plowed chernozems is the most important process. The loss of organic matter from the upper soil meter in $230-240$ years of the soil tillage proceeds with an average rate of $0.41 \mathrm{t} /$ ha per year. In the layer of $0-30 \mathrm{~cm}$, the most intense loss of humus takes place in the first $40-50$ years of tillage and comprises $0.61 \mathrm{t} /$ ha per year. During the subsequent period $(40(50)$ to $230(240)$ years), it decreases to about $0.09 \mathrm{t} / \mathrm{ha}$ per year.

In the first 100 years of plowing, we observe the accumulation of carbonates within the 2-m-deep layer; then, the amount of carbonates somewhat decreases, which attests to their leaching. In the first $100-150$ years, the radiocarbon age of carbonates in the deep soil layer $(130-150 \mathrm{~cm})$ decreases, i.e., the rejuvenation of carbonates takes place. In the subsequent period, the radiocarbon ages of the carbonates increase again up to the values typical of the virgin chernozems. The rejuvenation of carbonates can be 
Table 7. Radiocarbon ages of humus and carbonates in some chernozems of the investigated agrochronosequences (noncalibrated dates)

\begin{tabular}{|c|c|c|c|}
\hline Plot & Depth, cm & Laboratory number & Radiocarbon age, yrs \\
\hline \multicolumn{4}{|c|}{ Safonovka, humus } \\
\hline \multirow{3}{*}{ Virgin land, pit 1} & $10-20$ & $\mathrm{Ki}-18212$ & $530 \pm 50$ \\
\hline & $30-40$ & $\mathrm{Ki}-18354$ & $1670 \pm 90$ \\
\hline & $50-60$ & $\mathrm{Ki}-18353$ & $2430 \pm 80$ \\
\hline \multirow{3}{*}{ Arable, 140 yrs., pit 3} & $10-20$ & $\mathrm{Ki}-18215$ & $970 \pm 70$ \\
\hline & $30-40$ & $\mathrm{Ki}-18214$ & $1650 \pm 60$ \\
\hline & $50-60$ & $\mathrm{Ki}-18213$ & $3010 \pm 70$ \\
\hline \multirow{3}{*}{ Arable, 160 yrs., pit 5} & $10-20$ & Ki-18218 & $940 \pm 60$ \\
\hline & $30-40$ & $\mathrm{Ki}-18217$ & $2410 \pm 50$ \\
\hline & $50-60$ & $\mathrm{Ki}-18216$ & $2830 \pm 80$ \\
\hline \multirow{3}{*}{ Arable, 230 yrs., pit 7} & $10-20$ & Ki-18355 & $1040 \pm 60$ \\
\hline & $30-40$ & $\mathrm{Ki}-18211$ & $1730 \pm 70$ \\
\hline & $50-60$ & Ki-18219 & $3650 \pm 80$ \\
\hline \multicolumn{4}{|c|}{ Safonovka, carbonates } \\
\hline & $60-70$ & $\mathrm{Ki}-18366$ & $4810 \pm 160$ \\
\hline Virgin land, pit 1 & $130-140$ & $\mathrm{Ki}-18360$ & $10910 \pm 160$ \\
\hline \multirow[t]{2}{*}{ Virgin land, pit 2} & $130-140$ & $\mathrm{Ki}-18361$ & $10060 \pm 160$ \\
\hline & $60-70$ & Ki-18367 & $4400 \pm 100$ \\
\hline \multirow[t]{2}{*}{ Arable, 140 yrs., pit 3} & $130-140$ & $\mathrm{Ki}-18362$ & $5430 \pm 90$ \\
\hline & $60-70$ & $\mathrm{Ki}-18368$ & $5000 \pm 80$ \\
\hline \multirow[t]{2}{*}{ Arable, 160 yrs., pit 5} & $130-140$ & $\mathrm{Ki}-18357$ & $7540 \pm 60$ \\
\hline & $60-70$ & Ki-182 & $5420 \pm 180$ \\
\hline Arable, 230 yrs., pit 7 & $130-140$ & $\mathrm{Ki}-182$ & $8700 \pm 100$ \\
\hline Arable, 230 yrs., pit 8 & $130-140$ & $\mathrm{Ki}-18363$ & $11600 \pm 100$ \\
\hline \multicolumn{4}{|c|}{ Zhimolostnoe, carbonates } \\
\hline \multirow{2}{*}{ Virgin land, pit 1} & $70-80$ & $\mathrm{Ki}-17357$ & $7560 \pm 110$ \\
\hline & $130-140$ & $\mathrm{Ki}-17358$ & $4990 \pm 240$ \\
\hline \multirow{2}{*}{ Arable, 100 yrs., pit 3} & $70-80$ & $\mathrm{Ki}-17359$ & $7490 \pm 140$ \\
\hline & $150-160$ & $\mathrm{Ki}-17360$ & $4160 \pm 70$ \\
\hline \multirow{2}{*}{ Arable, 240 yrs., pit 10} & $70-80$ & $\mathrm{Ki}-17364$ & $10050 \pm 220$ \\
\hline & $120-140$ & $\mathrm{Ki}-17365$ & $7690 \pm 190$ \\
\hline
\end{tabular}

explained by the biogenic calcification of the soil profile, whereas their ageing may be related to the ascending migration of ancient carbonates from the deep soil layers in the old-arable chernozems [42] against the background of a general leaching of carbonates from the upper $2 \mathrm{~m}$ of the soil profiles. This problem requires further studies.

The redistribution of humus, carbonates, and clay, as well as changes in the structural state of the cherno- zems in the course of their plowing, is greatly affected by the activity of burrowing animals that causes certain stages in the development of arable chernozems. In contrast to a simple exponential development, it leads to a more complicated development with changes in its direction. A gradual accumulation of the results of different processes (argillization, loss of humus, soil mixing by burrowing animals, etc.) changes the conditions of other processes and alters their rate and direction. 


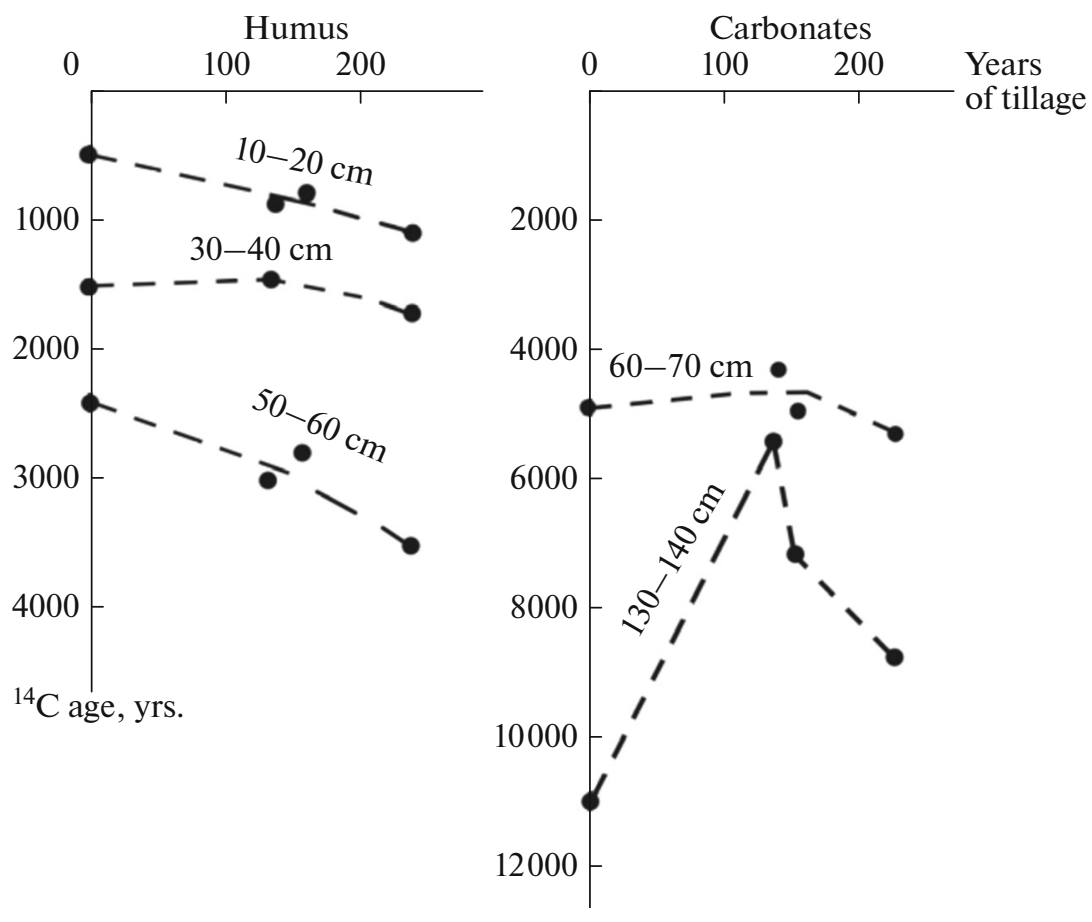

Fig. 7. Changes in the radiocarbon ages of humus and carbonates at different depths as dependent on the duration of tillage in the Safonovka agrochronosequence of chernozems.

Such changes mark the transition to a new stage of the soil development.

\section{ACKNOWLEDGMENTS}

This study was supported by the Russian Foundation for Basic Research, project no. 12-05-97512p_center_a.

\section{REFERENCES}

1. Agroecological Status of Chernozems in the Central Chernozemic Region, Ed. by A. P. Shcherbakov and I. I. Vasenev (Kursk, 1996) [in Russian].

2. P. G. Aderikhin, "Transformation of chernozems in the central chernozemic region after agricultural use," in Chernozems of the Central Chernozem Region and Their Fertility (Nauka, Moscow, 1964), pp. 61-89 [in Russian].

3. E. A. Afanas'eva, Chernozems of the Central Russian Upland (Nauka, Moscow, 1966) [in Russian].

4. B. P. Akhtyrtsev and A. B. Akhtyrtsev, "Changes in the humus state of forest-steppe and steppe chernozems resulting from their long-term plowing and sealing under burial mounds," Eurasian Soil Sci. 35, 123-131 (2002).

5. B. P. Akhtyrtsev and G. A. Shevchenko, "Influence of agriculture on gray forest soils in the western part of the central chernozemic region," Prochvoved. Agrokhim., No. 2, 31-48 (1970).

6. B. P. Akhtyrtsev and A. S. Shchetinina, Transformation of Gray Forest Soils of the Central Russian Forest-Steppe
Caused by Agricultural Use (Mordovian State Univ., Saransk, 1969) [in Russian].

7. M. S. Bruk, "Transformation of chernozems caused by prolonged agricultural use," Pochvovedenie, No. 8, 124-127 (1979).

8. M. S. Bruk, "Impact of human activities on evolution of chernozems," Pochvovedenie, No. 3, 24-32 (1975).

9. L. S. Butova, O. A. Parfenova, and A. M. Shcherbakov, "Argillization of chernozems under different uses," Proceedings of Conf. of Students and Post-Graduate Students on Fundamental Science "Lomonosov-96," Moscow (Moscow, 1996), p. 10.

10. A. V. Gedymin and I. G. Pobedintseva, "Influence of long-term plowing on the properties of ordinary chernozems," Pochvovedenie, No. 5, 35-46 (1964).

11. A. V. Gedymin and A. T. Kharitonychev, "Use of old cartographic materials for analysis of landscapes," in Modern Problems in Geography (Nauka, Moscow, 1964), pp. 298-302.

12. M. A. Glazovskaya, "Agrogenic transformation of factors and mechanisms of humus reserves in the massifs of arable soils," Proceedings of IV All-Russian Conf. "Problems of Soil Evolution" (Pushchino, 2003), pp. 201-210.

13. P. S. Denisov, Soil of Voronezh and Kursk Oblasts and Their Agricultural Use (Voronezh. Obl. Izd., Voronezh, 1935) [in Russian].

14. V. V. Dokuchaev, Russian Chernozem (Imper. Vol'noe Ekon. O-vo, St. Petersburg, 1883) [in Russian].

15. I. V. Ivanov and E. D. Tabanakova, "Changes in the thickness of humus horizons and the Holocene evolution of East European chernozems (mechanisms, fac- 
tors, and regularities)," Eurasian Soil Sci. 36, 917-930 (2003).

16. F. I. Kozlovskii, Modern Natural and Anthropogenic Processes in Soil Evolution (Nauka, Moscow, 1991) [in Russian].

17. F. I. Kozlovskii, "Evolution of arable soils as a subject of genetic-geographical soil science," in Theory and Methods of Study of Soil Cover (GEOS, Moscow, 2003), pp. 451-463.

18. T. P. Kokovina, "Soil processes in the deep typical arable chernozem," Pochvovedenie, No. 9, 13-23 (1978).

19. P. A. Kostychev, "The travel notes. Treatment and fertilization of chernozems," Sel. Khoz. Lesovod., No. 8, 293-315 (1886).

20. P. A. Kostychev, "What is the difference between new steppe soils and arable and fallow soils?" Zemledel'cheskaya Gazeta, No. 35, 620-623 (1881).

21. I. A. Krupenikov, Soil Cover of Moldova: Past, Present, Monitoring, and Forecast (Stiintsa, Chisinau, 1992) [in Russian].

22. N. S. Kukharuk, Yu. G. Chendev, and A. N. Petin, "Micromorphological features of organic matter upon agrogenic transformation of soils in the forest-steppe zone," Nauch. Ved. Bel. Gos. Univ., Estestv. Nauki, No. 15, 168-179 (2011).

23. A. A. Lazarev, Influence of Crops on the Properties of Forest-Steppe Chernozems (Academy of Sciences of Soviet Union, Moscow, 1936) [in Russian].

24. I. I. Lebedeva, "Hydrological profiles of typical chernozems and agrochernozems with migrational forms of pedogenic carbonates," Eurasian Soil Sci. 35, 10761084 (2002).

25. V. V. Medvedev, "Physical degradation of chernozem: reasons, consequences, and elimination methods," in Advanced Soil Science (Nauka, Moscow, 1986), pp. 23-26.

26. D. S. Orlov, O. N. Biryukova, and N. I. Sukhanova, Organic Matter of Russian Soils (Nauka, Moscow, 1996) [in Russian].

27. A. M. Pankov, "Subzones of chernozem in Voronezh region," Izv. Dokuchaev. Pochv. Kom., Nos. 1-2, 4551 (1913).

28. A. M. Pankov, Data on Natural and Historical Studies in Voronezh Region, Section IV: Geology and Soils. Valuiskiy Uezd (Moscow, 1922), No. 1.

29. E. I. Parfenova and E. A. Yarilova, Manual on Micromorphological Studies in Soil Science (Nauka, Moscow, 1977) [in Russian].

30. Soil-Agrochemical Basis of Sustainable Land Agriculture in the Central Chernozemic Region, Ed. by N. Z. Milashchenko (Agropromizdat, Moscow, 1991) [in Russian].

31. Provincial maps, county plans, maps, atlases, and town plans, Russian State Archive of Ancient Acts (RGADA), Fund 138, File 157-159.

32. M. I. Sidorov, N. I. Khabarov, I. M. Nebol'sin, and N. I. Zezyukov, Efficiency and Improvement of Land Agricultural Systems in the Central Chernozemic Region
(Tsentral'no-Chernozem. Knizh. Izd., Voronezh, Voronezh, 1986) [in Russian].

33. Z. A. Sinkevich, Modern Processes in Chernozems of Moldavia (Shtiintsa, Chisinau, 1989) [in Russian].

34. N. P. Sorokina and B. M. Kogut, "The dynamics of humus content in arable chernozems and approaches to its study," Pochvovedenie, No. 2, 178-184 (1997).

35. G. I. Uvarov, Mikhailovskaya virgin land as an object for comparing the properties of virgin and anthropogenic soils in northeastern Ukraine, Inform. Listok (Kharkov) No. 136-97 (1997).

36. T. I. Ushacheva and S. S. Zvyagintsev, "Dynamics of morphological properties of dark chestnut residualsolonetzic soils as the result of agricultural use," Proceedings of International Symp. "Steppes of Northern Eurasia: Strategy of Conservation of Natural Diversity and Steppe Nature Management in 21st Century" (Orenburg, 2000), pp. 385-386.

37. O. S. Khokhlova, Yu. G. Chendev, T. N. Myakshina, and V. A. Shishkov, "The pool of pedogenic carbon in the soils of different types and durations of use as croplands in the forest-steppe of the Central Russian Upland," Eurasian Soil Sci. 46, 530-540 (2013). doi 10.1134/S1064229313050062

38. Yu. G. Chendev, Evolution of Forest-Steppe Soils of the Central Russian Upland in the Holocene (GEOS, Moscow, 2008) [in Russian].

39. Y. G. Chendev, A. L. Aleksandrovskii, O. S. Khokhlova, L. G. Smirnova, L. L. Novykh, and A. V. Dolgikh, "Anthropogenic evolution of dark gray forest-steppe soils in the southern part of the Central Russian Upland," Eurasian Soil Sci. 44, 1-12 (2011).

40. D. I. Shcheglov, Chernozems of the Central Russian Plain and Their Evolution Affected by Natural and Anthropogenic Factors (Nauka, Moscow, 1999) [in Russian].

41. IUSS Working Group WRB, World Reference Base for Soil Resources 2014, International Soil Classification System for Naming Soils and Creating Legends for Soil Maps, World Soil Resources Reports No. 106 (Food Agriculture Organization, Rome, 2014).

42. O. S. Khokhlova, Yu. G. Chendev, and T. N. Myakshina, "Change in pedogenic carbon stocks under different types and duration of agricultural management practices in the central Russian forest steppe," in Sustainable Agroecosystems in Climate Change Mitigation, Ed. by M. Oelbermann (Wageningen Academic, Wageningen, 2014), pp. 33-52. doi 10.3920/978-908686-788-2_2

43. O. S. Khokhlova, Yu. G. Chendev, T. N. Myakshina, A. L. Alexandrovskiy, and A. A. Khokhlov, "Evolution of Chernozems in the southern forest-steppe of the Central Russian Upland under long-term cultivation examined in the agro-chronosequences," Quat. Int. 365, 175-189 (2015). doi 10.1016/j.quaint.2014.10.012

Translated by D. Konyushkov 